\title{
Estimasi Fungsi Permintaan Dan Elastisitas Permintaan Beras di Kota Medan
}

\author{
${ }^{1}$ Cyprianus PH. Saragi *, ${ }^{2}$ Palentina Pia Sinaga \\ ${ }^{1,2}$ Program Studi Agribisnis, Fakultas Pertanian, Unika Santo Thomas \\ Email :*Cyprianus.phs07@gmail.com
}

\begin{abstract}
Abstrak
Padi yang setelah digiling berubah menjadi beras, merupakan salah satu komoditas pertanian yang ada di Kota Medan. Penelitian ini bertujuan untuk mengidentifikasi faktor-faktor yang mempengaruhi permintaan beras di Kota Medan. dan menganalisis elastisitas permintaan beras di Kota Medan. Data yang digunakan dalam penelitian ini adalah data time series ( tahun 2000 - tahun 2019), analisis data dengan menggunakan regresi linier berganda. Koefisien determinasi $\left(\mathrm{R}^{2}\right)$ sebesar 0,72 menunjukkan bahwa sekitar $72 \%$ permintaan beras di Kota Medan dijelaskan oleh harga beras, harga jagung, harga ubi kayu, harga telur, pendapatan per kapita, dan jumlah penduduk, sedangkan $28 \%$ sisanya dijelaskan oleh variabel lain yang tidak dimasukkan dalam model. Hasil uji over-all menunjukkan bahwa harga beras, harga jagung, harga ubi kayu, harga telur, pendapatan per kapita, dan jumlah penduduk secara simultan berpengaruh nyata terhadap permintaan beras. Berdasarkan uji parsial, variabel harga jagung, harga ubi kayu, pendapatan per kapita, dan jumlah penduduk berpengaruh positif dan signifikan sedangkan variabel harga beras dan harga telur berpengaruh positif dan tidak signifikan. Elastisitas harga beras adalah inelastis, elastisitas silang dari jagung dan ubi kayu dengan beras bertanda positif atau substitusi serta elastisitas silang antara telur dengan beras bertanda negatif atau komplementer, dilihat dari elastisitas pendapatan beras adalah barang normal.
\end{abstract}

Kata kunci : fungsi permintaan beras, elastisitas permintaan.

\section{Abstract}

Paddy which after being milled turns into rice, is one of the agricultural commodities in the City of Medan. This study aims to identify the factors that influence the demand for rice in Medan City and analyze the elasticity of rice demand in Medan City. The data used in this study are time series data (2000 - 2019), data analysis using multiple linear regression. The coefficient of determination $\left(R^{2}\right)$ of 0.72 indicates that around $72 \%$ of rice demand in Medan City is explained by rice prices, maize prices, cassava prices, egg prices, per capita income, and population, while the remaining $28 \%$ is explained by other variables which is not included in the model. The result of the over-all test shows that the price of rice, the price of corn, the price of cassava, the price of eggs, the income per capita, and the population simultaneously have a significant effect on rice demand. Based on the partial test, the variables of maize prices, cassava prices, per capita income, and population have a positive and significant effect, while the variables of rice prices and egg prices have a positive and insignificant effect. The price elasticity of rice is inelastic, the cross elasticity of corn and cassava with rice has a positive sign or substitution and the cross elasticity of eggs and rice is negative or complementary, seen from the income elasticity of rice is a normal good.

Keywords : function of demand for rice, elasticity of demand

\section{PENDAHULUAN}

Salah satu komoditas tanaman pangan yang memiliki posisi paling penting dalam pembangunan pertanian adalah beras. Beras adalah makanan pokok yang dikonsumsi oleh hampir $90 \%$ penduduk Indonesia (Amang, 1999).

Meski pada tahun 2018 produktivitas padi mencatat angka tertinggi dibanding 4 tahun sebelumnya, di tahun ini luas panen menurun drastis. Penurunan luas panen sejak 2015 mengindikasikan terjadinya konversi lahan minimal sejak tahun tersebut.

Permintaan beras juga dipengaruhi oleh harga beras itu sendiri, harga jagung, harga ubi kayu, dan harga telur. Harga beras tertinggi terjadi pada tahun 2016 dan terendah terjadi pada tahun 2019. Harga jagung tertinggi terjadi pada tahun 2014 dan terendah pada tahun 2015 Harga ubi kayu tertinggi terjadi pada tahun 2019 dan terendah tahun 2018. Harga telur tertinggi terjadi pada tahun 2017 dan terendah terjadi pada tahun 2015 .

Permintaan beras juga dipengaruhi oleh pendapatan masyarakat. Semakin tinggi pendapatan maka permintaan terhadap beras akan meningkat sampai pada tingkat tertentu (Winarto, 2010). Secara rata-rata tingkat pertumbuhan pendapatan per kapita masyarakat meningkat $4,10 \%$ per tahun.

Permintaan beras di Kota Medan secara ratarata meningkat setiap tahunnya meskipun ada penurunan permintaan beras pada tahun 2015-2017. Setelah mengalami penurunan, permintaan beras cenderung mengalami peningkatan pada tahun-tahun berikutnya. 
Rumusan masalah yaitu

1. Faktor harga beras, harga jagung, harga ubi kayu, harga telur, pendapatan penduduk, dan jumlah penduduk mempengaruhi permintaan beras di Kota Medan?

2. Bagaimana elastisitas permintaan beras di Kota Medan?

3.

Tujuan Penelitian

1. Menganalisis faktor harga beras, harga jagung, harga ubi kayu, harga telur, pendapatan penduduk, dan jumlah penduduk terhadap permintaan beras di Kota Medan.

2. Menganalisis elastisitas harga, elastisitas pendapatan, dan elastisitas silang beras di Kota Medan.

Menurut Sukirno (2005) permintaan seseorang atau suatu masyarakat atas suatu barang ditentukan oleh banyak faktor, diantaranya yang terpenting adalah:

a. Harga barang itu sendiri

Semakin rendah harga suatu komoditi, semakin banyak jumlah yang akan diminta, apabila faktor lain dianggap tetap.

b. Harga barang lain yang mempunyai kaitan erat dengan barang tersebut

Hubungan antara sesuatu barang dengan berbagai jenis barang lainnya dapat dibedakan dalam tiga golongan, yaitu: barang pengganti (substitusi), barang pelengkap (komplementer), dan barang yang tidak mempunyai kaitan sama sekali (barang netral).

Menurut Arsyad (1995) dalam ilmu ekonomi dikenal tiga elastisitas permintaan, yaitu:

a. Elastisitas Harga (Ep)

Elastisitas harga dapat diperoleh dengan cara:

$E p=\frac{\text { persentase perubahan jumlah barang yang diminta }}{\text { persentase perubahan harga }}$

1) Bila Ep $>1$, permintaan elastis.

2) Bila $\mathrm{Ep}<1$, permintaan inelastis.

3) Bila $E p=1$, elastisitas tunggal (unitary elasticity).

4) Bila $\mathrm{Ep}=0$, permintan inelastis sempurna.

5) Bila $\mathrm{Ep}=\sim$, permintaan elastis sempurna.

b. Elastisitas Pendapatan $\left(\mathrm{E}_{\mathrm{I}}\right)$

Elastisitas pendapatan dapat diperoleh dengan cara:

$\mathrm{E}_{\mathrm{I}}=\frac{\text { persentase perubahan jumlah barang yang diminta }}{\text { persentase perubahan pendapatan }}$

1) $\mathrm{E}_{\mathrm{I}}<0$, barang inferior

2) $0<\mathrm{E}_{\mathrm{I}}<1$, barang normal

3) $E_{\mathrm{I}}>1$, barang mewah

c. Elastisitas Silang (Ec)

Besarnya elastisitas silang dapat di hitung dengan rumus:

$E c=\frac{\text { persentase perubahan jumlah barang } \mathrm{X} \text { yang diminta }}{\text { a }}$

persentase perubahan harga barang $\mathrm{Y}$

1) Elastisitas bernilai positif maka golongan barang substitusi
2) Elastisitas bernilai negatif maka golongan barang komplementer

\section{METODE PENELITIAN}

Penentuan lokasi penelitian ditentukan secara sengaja atau purposif. Lokasi penelitian yang dipilih adalah Kota Medan karena makanan pokok di Kota Medan adalah beras.

Jenis data yang digunakan dalam penelitian adalah data sekunder meliputi: data permintaan yaitu harga beras, harga jagung, harga ubi kayu, harga telur, pendapatan penduduk, dan jumlah penduduk. Data yang digunakan merupakan data time series dari tahun 2000-2019 yang diperoleh dari berbagai instansi terkait seperti Badan Pusat Statistik Kota Medan, Dinas Perindustrian dan Perdagangan Kota Medan, dan Dinas Ketahanan Pangan Kota Medan.

Metode yang digunakan untuk menganalisis data adalah regresi linear berganda dengan rumus sebagai berikut:

$$
\begin{aligned}
& \text { Qd }=b_{0}+b_{1} X_{1}+b_{2} X_{2}+b_{3} X_{3}+b_{4} X_{4}+b_{5} \\
& X_{5}+b_{6} X_{6}+e \\
& \text { Di mana: } \\
& \text { Qd = Jumlah permintaan beras } \\
& b_{0}=\text { Konstanta } \\
& X_{1}=\text { Harga beras tahun } t(R p / k g) \\
& X_{2}=\text { Harga jagung tahun } \mathrm{t}(\mathrm{Rp} / \mathrm{kg}) \\
& \mathrm{X}_{3}=\text { Harga singkong tahun } \mathrm{t}(\mathrm{Rp} / \mathrm{kg}) \\
& \mathrm{X}_{4}=\text { Harga telur tahun } \mathrm{t}(\mathrm{Rp} / \mathrm{kg}) \\
& \mathrm{X}_{5}=\text { Pendapatan penduduk Kota Medan } \\
& \quad \text { pada tahun } \mathrm{t}(\mathrm{Rp}) \\
& \mathrm{X}_{6}=\text { Jumlah penduduk Kota Medan dalam } \\
& \text { tahun } \mathrm{t} \text { (jiwa) } \\
& \mathrm{b}_{1}-\mathrm{b}_{6} \quad=\text { Koefisien regresi } \\
& \mathrm{e} \quad=\text { error }
\end{aligned}
$$

Untuk menguji hasil perhitungan agar mendapat hasil yang terbaik, maka dilakukan uji statistik dan uji asumsi klasik.Uji statistik meliputi uji $\mathrm{R}^{2}$, uji $\mathrm{F}$, dan uji t sedangkan uji asumsi klasik meliputi uji multikolinearitas, uji heterokedastisitas, uji autokorelasi, dan uji normalitas.

\section{HASIL DAN PEMBAHASAN}

Permintaan beras di Kota Medan dari tahun 2000 sampai 2019 cenderung mengalami fluktuasi. Permintaan beras tertinggi terjadi pada tahun 2019 yaitu sebesar 295.691 ton, sedangkan permintaan beras terendah terjadi pada tahun 2005 yaitu sebesar 271.988 ton (BPS, 2020).

Dari hasil analisis faktor yang mempengaruhi permintaan beras di Kota Medan dengan menggunakan SPSS Statistic 19.0 di peroleh output (semua variabel ditransformasi kedalam bentuk logaritma natural karena sebelumnya ditemukan gejala multikolinearitas) sebagai berikut: 
Tabel 1. Koefisien Regresi Permintaan Beras di Kota Medan

\begin{tabular}{|c|c|c|c|c|c|c|c|c|}
\hline \multirow{2}{*}{\multicolumn{2}{|c|}{ Model }} & \multicolumn{2}{|c|}{$\begin{array}{c}\text { Unstandardized } \\
\text { Coefficients }\end{array}$} & \multirow{2}{*}{$\begin{array}{c}\text { Standardized } \\
\text { Coefficients } \\
\text { Beta }\end{array}$} & \multirow[b]{2}{*}{$\mathrm{T}$} & \multirow[b]{2}{*}{ Sig. } & \multicolumn{2}{|c|}{$\begin{array}{l}\text { Collinearity } \\
\text { Statistics }\end{array}$} \\
\hline & & $\mathrm{B}$ & Std. Error & & & & $\begin{array}{c}\text { Toleran } \\
\text { ce }\end{array}$ & VIF \\
\hline \multirow[t]{7}{*}{$\overline{1}$} & (Constant) & 17.968 & 3492.200 & & 81.945 & .000 & & \\
\hline & Harga Beras & -.754 & .491 & -.394 & -1.534 & $.149^{\text {tn }}$ & .324 & 3.091 \\
\hline & Harga Jagung & 2.780 & 1.155 & .803 & 2.407 & $.032^{*}$ & .191 & 5.226 \\
\hline & Harga Ubi Kayu & 4.656 & 2.026 & .652 & 2.299 & $.039^{*}$ & .265 & 3.774 \\
\hline & Harga Telur & -.095 & .359 & -.083 & -.265 & $.795^{\mathrm{tn}}$ & .215 & 4.647 \\
\hline & $\begin{array}{l}\text { Pendapatan Per } \\
\text { Kapita }\end{array}$ & .006 & .002 & .932 & 2.347 & $.035^{*}$ & .135 & 7.397 \\
\hline & Jumlah Penduduk & .006 & .002 & .694 & 2.499 & $.027^{*}$ & .276 & 3.622 \\
\hline
\end{tabular}

Sumber: Data sekunder diolah

$\begin{array}{ll}\text { Keterangan: } & *=\text { nyata pada } \alpha=0.05 \\ & \text { tn }=\text { tidak nyata } \\ & \mathrm{R}^{2}=0.723 \\ & \text { F-hit }=5.652 \\ & \text { t-tabel }(0.05)=2.16\end{array}$

Fungsi permintaan beras di Kota Medan adalah sebagai berikut:

Ln Qd $=17,968-0,75 \operatorname{Ln} \mathrm{P}_{\mathrm{b}}+2,78 \operatorname{Ln} \mathrm{P}_{\mathrm{j}}+4,66 \mathrm{Ln}$ $\mathrm{P}_{\mathrm{uk}}-0,10 \operatorname{Ln} \mathrm{P}_{\mathrm{t}}+0,01 \operatorname{Ln} \mathrm{I}_{\mathrm{p}}+0,01 \mathrm{Ln}$

Nilai $R^{2}=0,72$ artinya sekitar $72 \%$ permintaan beras di Kota Medan dijelaskan oleh harga beras, harga jagung, harga ubi kayu, harga telur, pendapatan per kapita, dan jumlah penduduk, sedangkan $28 \%$ sisanya dijelaskan oleh variabel lain yang tidak dimasukkan dalam model.

Berdasarkan hasil pengolahan data pada tingkat kepercayaan $95 \%$ didapatkan $\mathrm{F}_{\text {hitung }}$ sebesar 5,65, sedangkan $F_{\text {tabel }}$ sebesar 2,85. Karena $F_{\text {hitung }}(5,65)>$ $\mathrm{F}_{0,05}(2,85)$, dapat disimpulkan bahwa harga beras, harga jagung, harga ubi kayu, harga telur, pendapatan per kapita, dan jumlah penduduk secara bersamasama berpengaruh nyata terhadap permintaan beras di Kota Medan.

Berdasarkan hasil pengolahan data didapatkan $t_{\text {hitung }}$ untuk masing-masing variabel bebas dan $t_{\text {tabel }}$ pada tingkat kepercayaan 95\% adalah 2,16. Dengan demikian dapat disimpulkan bahwa harga jagung $\left(t_{\text {hitung }} 2,41>t_{\text {tabel }} 2,16\right.$ ), harga ubi kayu ( $t_{\text {hitung }} 2,30$ $>t_{\text {tabel }} 2,16$ ), pendapatan per kapita ( $t_{\text {hitung }} 2,35>t_{\text {tabel }}$ 2,16 ), dan jumlah penduduk ( $t_{\text {hitung }} 2,50>t_{\text {tabel }} 2,16$ ) secara parsial berpengaruh nyata terhadap permintaan beras di Kota Medan, sedangkan harga beras ( $t_{\text {hitung }} 1,53<\mathrm{t}_{\text {tabel }} 2,16$ ) dan harga telur ( $t_{\text {hitung }}$ $\left.0,27<t_{\text {tabel }} 2,16\right)$ tidak berpengaruh nyata terhadap permintaan beras di Kota Medan.

Nilai VIF dari harga beras, harga jagung, harga ubi kayu, harga telur, pendapatan per kapita, dan jumlah penduduk lebih kecil dari 10, maka disimpulkan bahwa tidak terjadi gejala multikolinearitas.

Untuk melihat gejala heterokedastisitas digunakan uji Scatterplot. Diketahui bahwa plot tidak membentuk pola yang jelas, sehingga dinyatakan bahwa tidak terjadi gejala heterokedastisitas.

Berdasarkan hasil pengujian autokorelasi diperoleh nilai DW hitung sebesar 2,00. Dengan mengacu pada Tabel Durbin Watson pada $\alpha=0,05$ diperoleh nilai dU sebesar 2,16 untuk $\mathrm{n}=20$ dan $\mathrm{k}=$ 6 . Dari hasil tersebut di peroleh nilai $4-\mathrm{dU}=1,84$. Karena nilai DW hitung berada di antara dU sampai dengan 4-dU maka dapat disimpulkan tidak terjadi gejala autokorelasi.

Uji normalitas diperoleh dengan menggunakan uji normalitas Kolmogorov Smirnov. Uji ini di lihat dengan membandingkan nilai Asymp. Sig. (2-arah) dan nilai signifikansinya pada taraf 0,05 . Nilai Asymp. Sig. (2-arah) sebesar 0,849 lebih besar dari taraf 0,05 sehingga dapat dinyatakan data terdistribusi normal.

Koefisien regresi harga beras sebesar 0,75 dengan tanda negatif yang berarti bahwa kenaikan harga beras sebesar $1 \%$ menyebabkan permintaan beras menurun sebesar $0,75 \%$.

Koefisien regresi harga jagung sebesar 2,78 dengan tanda positif yang berarti bahwa kenaikan harga jagung sebesar $1 \%$ menyebabkan permintaan beras meningkat sebesar 2,78\%.

Koefisien regresi harga ubi kayu sebesar 4,66 dengan tanda positif yang berarti bahwa kenaikan harga ubi kayu sebesar $1 \%$ menyebabkan permintaan beras meningkat sebesar $4,66 \%$.

Koefisien regresi harga telur sebesar 0,10 dengan tanda negatif yang berarti bahwa kenaikan harga telur sebesar $1 \%$ menyebabkan permintaan beras menurun sebesar $0,10 \%$.

Koefisien regresi pendapatan per kapita sebesar 0,01 dengan tanda positif yang berarti bahwa kenaikan pendapatan per kapita sebesar $1 \%$ menyebabkan permintaan beras meningkat sebesar $0,01 \%$. 
Diperoleh koefisien regresi jumlah penduduk sebesar 0,01 dengan tanda positif yang berarti bahwa kenaikan jumlah penduduk sebesar $1 \%$ menyebabkan permintaan beras meningkat sebesar $0,01 \%$.

Hasil analisis elastisitas permintaan beras di Kota Medan dapat di lihat pada Tabel 2. Nilai elastisitas permintaan tersebut dapat di jelaskan berikut ini:

\section{Elastisitas Harga}

Permintaan beras di Kota Medan bersifat inelastis karena nilai koefisien elastisitasnya lebih kecil dari 1 .

\section{Elastisitas Silang}

Besar elastisitas silang dari harga jagung adalah 0,33 dan elastisitas harga ubi kayu adalah 0,51 dengan tanda positif yang menunjukkan bahwa jagung dan ubi kayu adalah barang substitusi dari beras.

Sedangkan elastisitas silang dari harga telur adalah 0,01 dengan tanda negatif yang menunjukkan bahwa telur merupakan barang komplementer dari beras.

Nilai elastisitas pendapatan per kapita $0<\mathrm{E}_{\mathrm{I}}$ $<1$, hal ini menunjukkan bahwa beras merupakan barang normal (Sudarman (2000) dan Nugraheni (2008)).

Tabel 2. Nilai Elastisitas Permintaan Beras di Kota

\begin{tabular}{|l|c|c|c|}
\hline \multirow{2}{*}{\multicolumn{1}{c|}{ Variabel }} & \multicolumn{3}{|c|}{ Nilai Elastisitas } \\
\cline { 2 - 4 } & Harga & Silang & $\begin{array}{c}\text { Penda } \\
\text { patan }\end{array}$ \\
\hline Harga Beras & -0.10 & & \\
\hline Harga Jagung & & 0.33 & \\
\hline Harga Ubi Kayu & & 0.51 & \\
\hline Harga Telur & & -0.01 & \\
\hline Pendapatan Per Kapita & & & 0.002 \\
\hline
\end{tabular}

Sumber: Data sekunder diolah

\section{KESIMPULAN}

1. Harga beras, harga jagung, harga ubi kayu, harga telur, pendapatan per kapita, dan jumlah penduduk secara bersama-sama berpengaruh nyata terhadap permintaan beras di Kota Medan. Secara parsial, harga jagung, harga ubi kayu, pendapatan per kapita, dan jumlah penduduk berpengaruh nyata terhadap permintaan beras di Kota Medan, sedangkan harga beras dan harga telur tidak berpengaruh nyata terhadap permintaan beras di Kota Medan.

2. Elastisitas permintaan beras di Kota Medan bersifat inelastis karena nilai koefisien elastisitasnya lebih kecil dari 1. Elastisitas silang dari harga jagung adalah 0,33 dan dari harga ubi kayu adalah 0,51. Jagung dan ubi kayu merupakan barang substitusi dari beras. Sedangkan elastisitas silang dari harga telur adalah 0,01. Telur merupakan barang komplementer dari beras. Nilai elastisitas pendapatan perkapita adalah 0,002, hal ini menunjukkan bahwa beras merupakan barang normal.

\section{DAFTAR PUSTAKA}

Amang.B. dan M. H. Sawit.1999. Kebijakan Beras dan Pangan Nasional.IPB Press. Bogor.

Arsyad. 1995. Ekonomi Mikro. BPFE.Yogyakarta.

BPS. 2020. Kota Medan Dalam Angka 2020. BPS Kota Medan.

Dinas Ketahanan Pangan Kota Medan. 2020. Perkembangan Permintaan Beras Kota Medan. Dinas Ketahanan Pangan Kota Medan.

Dinas Perindustrian dan Perdagangan Kota Medan. 2020. Perkembangan Harga Beras, Harga Jagung, Harga Ketela Pohon, dan Harga Telur Tahun 2000-2019. Dinas Perindustrian dan Perdagangan Kota Medan.

Nugraheni. 2008. Analisis Permintaan Beras Pada Rumah Tangga Miskin di Kabupaten Demak. Universitas Sebelas Maret. Surakarta.

Sudarman, Ari. 2000. Teori Ekonomi Mikro Jilid 1 Edisi Ketiga.BPFE.Yogyakarta.

Sukirno. 2005. Pengantar Teori Mikro Ekonomi. PT Raja Grafindo Persada. Jakarta.

Winarto.2010. Analisis Permintaan dan Penawaran Beras di Jawa Tengah. Majalah Ilmiah Ekonomika Volume 13 Nomor 1, Februari 2010:1-46. 